Canadian University Music Review

Revue de musique des universités canadiennes

\title{
Kitsch, Camp, and Opera: Der Rosenkavalier
}

\section{Gary Le Tourneau}

Numéro 14, 1994

URI : https://id.erudit.org/iderudit/1014312ar

DOI : https://doi.org/10.7202/1014312ar

Aller au sommaire du numéro

\section{Éditeur(s)}

Canadian University Music Society / Société de musique des universités canadiennes

\section{ISSN}

0710-0353 (imprimé)

2291-2436 (numérique)

\section{Découvrir la revue}

\section{Citer cet article}

Le Tourneau, G. (1994). Kitsch, Camp, and Opera: Der Rosenkavalier. Canadian University Music Review / Revue de musique des universités canadiennes, (14), 77-97. https://doi.org/10.7202/1014312ar

\section{Résumé de l'article}

In her celebrated essay, "Notes on Camp," Susan Sontag identifies Richard Strauss's most famous opera, Der Rosenkavalier as forming part of the canon of "camp." What is it about this work and its relationship to fin-de-siècle Vienna which gives it over to the "camp" aesthetic?

In this article, the author examines the essence of the style known as camp, as derived from kitsch, another mode of "failed seriousness." Central to this investigation is the manner in which certain aesthetic objects can inhabit the realms of "high" or "serious" art and also that of popular culture. Hermann Broch, Theodor Adorno, and others suggest that kitsch is a parasitic ingredient in bourgeois culture and that this element can invade and "negate" an aesthetic object or experience. The historical imperatives found in romantic opera, bourgeois culture, and marginalized groups form an important element in defining the creations of modernist culture.

Part of our understanding of what constitutes "serious" art has at its centre ways of maintaining autonomy and refusing the prospect of "negating" itself. One way of experiencing and examining those works which "refuse the burden of autonomy" is through the categories of questionable or marginal sensibilities, in this case: kitsch and camp.

Der Rosenkavalier, with its fawning tribute to eighteenth-century Vienna, overt homage to Mozart, and its heralding of the composer's withdrawal from the avant-garde, proves to be a superb example of alternative sensibilities.
All Rights Reserved @ Canadian University Music Society / Société de musique des universités canadiennes, 1994
Ce document est protégé par la loi sur le droit d'auteur. L’utilisation des services d'Érudit (y compris la reproduction) est assujettie à sa politique d'utilisation que vous pouvez consulter en ligne.

https://apropos.erudit.org/fr/usagers/politique-dutilisation/ 


\section{KITSCH, CAMP, AND OPERA: DER ROSENKAVALIER*}

\section{Gary Le Tourneau}

Richard Strauss, once heralded as a trailblazer of modernism in opera, began to be perceived with Der Rosenkavalier, as a creator of operatic fluff. ${ }^{1} \mathrm{His}$ compositions following the heroic tone poems and the operas Salome and Elektra, occupy a position in relation to aesthetic value which is arguably marginal. They are too embracing of a kind of self-conscious posturing and selfconceit, and therefore they are not authentic aesthetic products. Yet they have not given themselves over completely to the realm of popular entertainment and culture. Their place in the canon is anything but secure, hovering as they do between art and recreation.

As early as March of 1900 Strauss remarked to Romain Rolland that the burden of romantic heroism was too much for him: "I am not a hero; I haven't got the necessary strength; I am not made for battle; I much prefer to go into retreat, to be peaceful and to rest. I haven't enough genius ... I don't want to make the effort. At this moment what I need is to make sweet and happy music. No more heroisms."

Strauss's rejection of the mantel of hero and his admission of lack of interest and commitment to heroic ideals places him in an aesthetic limbo. This nebulous area of artistic creation, in which the composer clearly saw himself, has now been

* I wish to thank Mary Cyr, Lise Viens, Eleanor Stubley, Don McLean, William Kinderman, Joan Backus and Jeremy Greenhouse for their support and encouragement. The support and understanding of my family and friends is also gratefully acknowledged. A version of this paper was presented at the 1993 meeting of the Canadian University Music Society in Ottawa, Ontario.

1 See Norman Del Mar, Richard Strauss: A Critical Commentary on his Life and Works (London: Barrie and Rockliff, 1962), 1:418-20. He writes, "Der Rosenkavalier also marks the turningpoint in Strauss's life as a contemporary composer in the vital sense of the word" (p. 418). See also the numerous assaults declaring this work to be an aesthetic regression in Nicolas Slonimsky's Lexicon of Musical Invective, 2nd ed. (New York: Coleman-Ross, 1965). Paul Rosenfeld's and Cecil Gray's denouncements of Der Rosenkavalier can be found in Slonimsky, p.195.

2 Richard Strauss, cited in Richard Strauss \& Romain Rolland: Correspondence, ed. Rollo Myers (London: Calder and Boyars, 1968), 132. 
described. In her celebrated essay "Notes on Camp," Susan Sontag identifies three main cultural sensibilities within modernism: "The first sensibility, that of high culture, is basically moralistic. The second sensibility, that of extreme states of feeling, represented in much contemporary 'avant-garde' art, gains power by a tension between moral and aesthetic passion. The third, Camp, is wholly aesthetic."3

Richard Strauss clearly, perhaps unwittingly, manoeuvered himself through all three of these sensibilities. The first sensibility, that of moralistic heroism, is incorporated in such works as Tod und Verklärung (1889) and Ein Heldenleben (1898). The second sensibility, that of extreme states of feeling-the avant-gardemanifests itself in his "expressionistic" operas Salome (1905) and Elektra (1908). He then goes one step further and adopts the third sensibility of "failed seriousness" beginning with Der Rosenkavalier (1910). Many of his critics have pointed to this element in their assessment of his talents. Joseph Kerman in Opera as Drama dismisses Strauss's entire operatic output because of its aesthetic posturing: "In the deepest sense the operas of Strauss and Puccini are undramatic, for their imaginative realm is a realm of emotional cant. They are unable to match any action, however promising, with anything but the empty form of drama. And the form is always there. Alarmingly precise, alarmingly false." ${ }^{4}$ Igor Stravinsky rejects Strauss's stage works because they are in fact, successful failures: "I would like to admit all Strauss operas to whichever purgatory punishes triumphant banality. Their musical substance is cheap and poor; it cannot interest a musician today." 5

Do Richard Strauss's operas after 1910 belong to the canon of serious artistic production, or are they a reactionary capitulation to bourgeois sentimentality-as Theodor Adorno and others have suggested? I would offer an alternative reading of Der Rosenkavalier, through the sensibility of "camp." Many critics, including Susan Sontag, argue that our assessment of aesthetic products must address not only intellectual and social constructs but also the significant influence of sensibility. This enables us to free ourselves from the "constant exercise" of cultivating good taste. Sontag points out that sensibilities are often ignored in our analysis and criticism of culture and its aesthetic goods. ${ }^{6}$

3 Susan Sontag, "Notes on Camp," in Against Interpretation (New York: Farrar, Straus \& Giroux, 1966), 287.

4 Joseph Kerman, Opera as Drama (New York: Alfred A. Knopf, 1956), 264.

5 Igor Stravinsky, Conversations with Stravinsky: Igor Stravinsky and Robert Craft (Garden City, New York: Doubleday, 1959), 83.

6 "The sensibility of an era is not only its most decisive, but also its most perishable, aspect. One may capture the ideas (intellectual history) and the behavior (social history) of an epoch without ever touching upon the sensibility or taste which informed those ideas, that behavior." Susan Sontag, "Notes on Camp," 276. 
Der Rosenkavalier is the result of the composer's entrapment, partially against his will, within the world of the aesthetic "other," the modernist. Der Rosenkavalier is the first of his so-called "reactionary" works which fully engages the sensibilities of kitsch and "camp." Sensibility, according to the Oxford Dictionary, is "the capacity for refined emotions; to be moved by the pathetic in literature or art." It has become an elusive term often confused with, or held to be synonymous with, sentimentality. ${ }^{7}$ Historically, kitsch and "camp" have been used to dismiss aesthetic creations which chose to identify fully with elements outside the realm of mainstream culture.

Kitsch and "camp" are used to identify aesthetic products which fail to meet the criteria of high or serious "art." They share a number of affinities: their origin is from continental Europe; they came into use as a description of "failed" art during the nineteenth century; and they are a rejection of the burden of being "art." In "Uses of Camp," Andrew Ross examines the source and meaning of these terms: "Kitsch, from the German, petty-bourgeois for pseudo-art, and Camp, more obscurely from the French se camper (to posture or flaunt)."8

Sarah Goodwin delineates the parallel development of post-industrial capitalism, romanticism and kitsch:

Kitsch derives directly from its place in postindustrial economy; this economy represents art as commodity. Thus its development in history directly parallels that of middle-class consumerism-and not coincidentally, of Romanticism as cultural phenomenon: kitsch and Romanticism emerged at the same historical moment. Although kitsch has long been associated with what is now called commodity culture, it has traditionally been viewed in the context of social class (as, for example, an instrument of mystification) ${ }^{9}$

In this century, cultural commentators such as Hermann Broch, Clement Greenberg, and Theodor Adorno have all dealt with the concept of kitsch. Hermann Broch, in "Notes on the Problem of Kitsch," argues that there is a definite division between art and non-art, the latter he refers to as kitsch, and that this development took place during the nineteenth century. ${ }^{10}$ Clement Greenberg

7 Roland Barthes formulates the problem as: "Why was 'sensibility,' at a certain moment, transformed into 'sentimentality'?" Roland Barthes, "From A Lover's Discourse" in A Barthes Reader, ed. Susan Sontag (New York: Noonday Press, 1980), 427.

8 Andrew Ross, "Uses of Camp," in No Respect: Intellectuals and Popular Culture (New York: Routledge, 1989), 145.

9 Sarah Webster Goodwin, "Domestic and Uncanny Kitsch in 'the Rime of the Ancient Mariner' and Frankenstein," in Tulsa Studies in Women's Literature 10, no. 1 (Spring 1991): 93-94.

10 "A clear line of demarcation seems to run straight across the artistic production of the age, dividing it into two basic and radically different groups, without any intermediary gradations: on 
offers the following explanation of the fundamental differences between avantgarde art and kitsch: "If the avant-garde imitates the processes of art, kitsch [...] imitates its effects." 11 Theodor Adorno, in The Philosophy of Modern Music, echoes these sentiments and goes one step further by assessing the commercial properties of the sensibility: "Music is inextricably bound up with what Clement Greenberg called the division of all art into kitsch and the avant-garde, and this kitsch-with its dictate of profit over culture-has long since conquered the social sphere." 12

Kitsch, to these critics, is the capitulation of culture into crass materialism; it negates process and goes directly for the emotional jugular. Richard Strauss's retroactive response to criticism of his opera Salome illuminates this attitude: "William the Second once said to his Intendant: 'I am sorry Strauss composed this Salome. I really like the fellow, but this will do him a lot of damage.' The damage enabled me to build the villa in Garmisch."13 The image of Strauss and his librettist Hugo von Hofmannsthal, as "commercial" creators, more concerned with commerce than with art, was a prominent image within the German press, as Rudolf Hermann's illustration suggests (figure 1).

Strauss made no secret of his unabashed embracing of the sentimental and mundane. Kitsch is an easy label to affix to Strauss's operatic creations, even those generally associated with his avant-garde or "expressionistic" period. ${ }^{14}$ The composer freely admitted to creating kitsch. He also felt that the genre of opera was the point at which kitsch and art collided. In a letter to Stefan Zweig in 1934 he posed the question, "Where does the kitsch end and the opera begin?" 15 Earlier the same year he also admitted his love of bourgeois posturing: "What suits me best are South German bourgeois sentimental jobs; but such bull's eyes as the Arabella duet and the Rosenkavalier trio don't happen everyday. Must one become seventy years old to recognize that one's greatest strength lies in creating kitsch." 16

the one hand we have work which reveals cosmic aspirations, and, on the other, kitsch." Hermann Broch, "Notes on the Problem of Kitsch," in Kitsch: The World of Bad Taste, ed. Gillo Dorfles (New York: Bell Publishing, 1969), 51-52.

11 Clement Greenberg, "The Avant-Garde and Kitsch," in Kitsch: The World of Bad Taste, 116.

12 Theodor Adorno, The Philosophy of Modern Music, trans. Anne G. Mitchell and Wesley V. Blomster (New York: Seabury Press, 1973), 10.

13 Richard Strauss, Recollections and Reflections, ed. Willi Schuh, trans. L.J. Lawrence (Westport, Connecticut: Greenwood Press, 1953), 152.

14 See Robin Holloway's “Salome: Art or Kitsch?" in Richard Strauss: Salome, ed. Derrick Puffett, Cambridge Opera Handbooks, (Cambridge: Cambridge University Press, 1989), 145-60.

15 A Confidential Matter: The Letters of Richard Strauss and Stefan Zweig, 1931-1935, trans. Max Knight (Berkeley: University of California Press, 1977), 87.

16 A Confidential Matter, 55. 


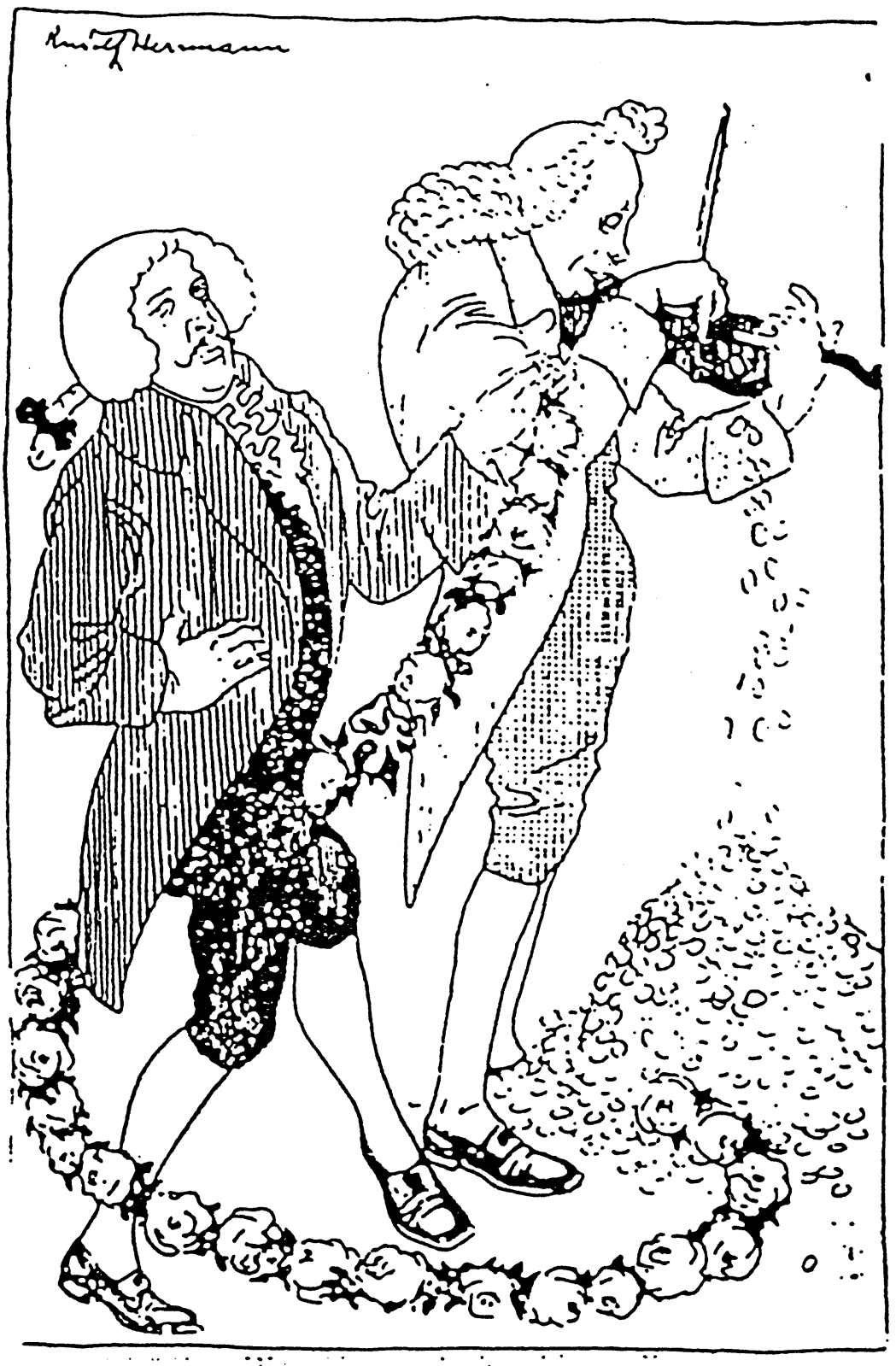

Figure 1: "Der Rosenkavaliers" taken from Richard Strauss: An Intimate Portrait by Kurt Wilhelm, trans. Mary Whitthal (London: Thames \& Hudson, 1989), 130. 
Strauss's rejection of both the burden of the German romantic tradition and the avant-garde is evidenced in Stefan Zweig's autobiography, The World of Yesterday: "He knew well indeed that as an art form opera was dead. 'But' he added, with a broad, Bavarian grin, 'I solved the problem by making a detour around it." 17 This detour involved the negation of the high art form of the musicdrama of Wagner. Strauss's retreat from the burden of the "heroic gestures" established in German romanticism led him in a new direction. The success and scandal of Salome and Elektra established the composer as, if not the leader of the avant-garde, certainly the leader of staging sexual neuropathology. He seemed determined to strike out on a new path, one which would relieve him of the burden of being revolutionary. The composer's flight from the avant-garde led him directly to the modernist sensibilities of kitsch and "camp." Of such sensibilities is Der Rosenkavalier made.

Broch, Greenberg, and Adorno propose that kitsch is a manipulative sensibility, a result of the mass production of cultural products in a bourgeois, postindustrial society. This development led directly to the sensibility of "camp," according to Susan Sontag: "Camp is the answer to the problem: how to be a dandy in the age of mass culture."18

Romanticism, the dominant force in nineteenth-century culture, derived much of its energy from an introspective anxiety. Central to this anxiety was the uncomfortable tension surrounding the nature and purpose of not just art but gender and sexuality as well. Like kitsch and "camp." with their basis in capitalist exploitation, gender and its mutability also became a dominant feature of romantic angst. ${ }^{19}$

By the early twentieth century, the mantel of being revolutionary, avantgarde, or "modern" was often thrust upon composers unwilling to accept the responsibility. Such a composer was Richard Strauss. In 1907, the publishers of the journal, Der Morgen requested that the composer who they described as the "Leader of the Moderns" and the "Head of the Avant-Garde," contribute an introductory essay to a volume on music. Strauss responded with the polemical "Is There an Avant-Garde in Music?" in which he clearly rejects the epithet given

17 Stefan Zweig, The World of Yesterday, trans. Cedar and Eden Paul (London: Cassell Publishers, 1987), 279.

18 Sontag, "Notes on Camp," 288.

19 "By the end of the nineteenth century, the trope of transvestism and transsexualism - perhaps because of a romantic interest in androgyny - had gained prominence, with such works as Theophile Gauthier's sensational Mademoiselle de Maupin (1834) and Honore de Balzac's Seraphita (1835) celebrating radical role reversals." Sandra M. Gilbert and Susan Gubar, No Man's Land: The Place of the Woman Writer in the Twentieth Century (New Haven: Yale University Press, 1989), vol. 2, Sexchanges, 326. 
him by the publishers: "Now I hate such statements from the bottom of my heart." 20

As much as he wished to disassociate himself as the leader of a revolutionary movement, he remained tarnished by the modernist image. Arnold Schönberg in 1923 saddled Strauss with the burden of responsibility when he declared: "I was never revolutionary. The only revolutionary in our time was Strauss." ${ }^{21}$ It seems no one wants to be a revolutionary. Peter Gay in his conspectus of modernism, Freud, Jews and Other Germans: Masters and Victims in Modernist Culture clearly elicits Strauss and his compositions as evoking a spirit of modernist titillation. $^{22}$

For Strauss, being a modernist meant fully identifying with the avant-garde, a marginality that, to him, seemed foreign and frightening. It was one thing to be titillating, but quite another to be avant-garde. During the early years of the twentieth century, Strauss's attempt to distance himself from the "modernists" was completely unsuccessful. With the success of Salome and Elektra, his association and absorption into the avant-garde were complete. In many centers, Vienna in particular, modernism and the avant-garde were concomitant with Jewishness and sexuality-the perverse. Strauss had clearly gone over to the "other," as Sander Gilman points out in "Strauss and the Pervert:"

Strauss, the arch-manipulator of audiences, had been overtaken by events: he had become, against his will, a "Jewish" composer, a "pervert." The financial and artistic breakthrough of Salome was achieved with a doubleedged sword. He had conquered the avant-garde; but in doing so he had engendered a "perverted" creation from which-protest as he might-he could not distance himself. ${ }^{23}$

20 Strauss, Recollections and Reflections, 12.

21 Arnold Schönberg, "New Music," in Style and Idea, ed. Leonard Stein, trans. Leo Black (London: Faber and Faber, 1975), 137.

22 "It is a commentary on the state of musical taste in Berlin at the turn of the century that the Philharmonic should have played Strauss more often than Mozart, and more than twice as often as Haydn. Brahms, then, was comfortably - or, rather, uncomfortably - lodged between the ancients and the moderns: not ancient enough to be, like Haydn, slighted; not modern enough to be, like Strauss, titillating." Peter Gay, "Aimez-Vous Brahms?" in Freud, Jews and Other Germans: Masters and Victims in Modernist Culture (Oxford: Oxford University Press, 1978), 246.

23 Sander L. Gilman, "Strauss and the Pervert," in Reading Opera, ed. Arthur Groos and Roger Parker (Princeton: Princeton University Press, 1988), 327. 
In Salome and Elektra, the composer ignored, or perhaps missed, the inherent homosexual implications within the texts. Although he admits purging Wilde's work of the "purple passages," homosexual iconography incessantly permeates the opera. In the encounter between Salome and Narraboth near the beginning of the opera, the title character makes known her knowledge of homosexual symbolism when she offers the Syrian "the little green flower," clearly a reference to the symbol of homosexuals in turn- of-the-century Paris. ${ }^{24}$ Elektra, his first collaboration with Hugo von Hofmannsthal, proved to be the vehicle for yet another manifestation of "perversion." Neither the composer nor the librettist seemed to protest or feel it necessary to remove the latent lesbianism of Elektra's speech to Chrysothemis. ${ }^{25}$

The composer's employment of homosexual references in his early operas clearly aligned him with the perverse, as Gilman suggests. Even though Strauss struggled valiantly in his subsequent operas to avoid the overt psycho-sexual titillation of his earlier creations, he was unwilling, or unable, to erase this element in subsequent works. Guilt by association, the offence of portraying as triumphant figures the "other," left him vulnerable to attack by both conservative and liberal opponents. Strauss and Hofmannsthal had purposely engendered their work with a sense of titillation, as Barbara Tuchman suggests:

24 "The iconography of the Salome story includes occasional homosexual references ... and Wilde makes it clear that both the Page and Herod are erotically attracted to Narraboth. More importantly Salome's offer to give Narraboth 'a little green flower' is a barely concealed indication that her ostensible heterosexuality must be understood as a substitution for homoerotic relationships and that at this level the work takes on autobiographical connotations: green carnations were a badge of Parisian homosexuals which Wilde adopted in the 1890s." Paul Banks, "Richard Strauss and the Unveiling of Salome," in Salome/Electra, ed. Nicholas John (London: John Calder, 1988), 10. This moment is contained in the score at rehearsal number 53, where Salome promises: "Du wirst das fur mich tun, Narraboth, und morgen, [...] werde ich eine kleine Blume fur dich fallen lassen, ein kleines grunes Blumchen." (You will do this for me, Narraboth, and tomorrow, [...] I will give you a little flower, a little green flower.)

25 Hanna B. Lewis perceives this as a sign of the influence of modernism. "Another modern psychological touch is in the latent Lesbianism shown in Electra's speeches to Chrysothemis. The scene in which she tries to persuade the younger and stronger of the two sisters to kill Aegisth and Klytämnestra, reeks with suggestions of this perversion... . It is an absolute sensual delight in the physical attributes of another woman." Hanna B. Lewis, "Salome and Electra: Sisters or Strangers," Orbis Litterarum 31 (1976): 130. Elektra's speech to Chrysothemis is quite lengthy; it begins at rehearsal number 49a of the full score and ends with the following declaration: "Ich spure durch die Kuhle deiner Haut das warme Blut hindurch, mit meiner Wange spur ich den Flaum auf deinem jungen Armen: Der bist voller Kraft, du bist schon, du bist wie eine Frucht an der Reife Tag." (I feel with my cheek the warm blood underneath your cool skin and feel your strong arms: you are full of strength, you are beautiful, you are like a fruit on the day of its ripening.) The Karl Bohm and Freidrich Gotz production of Elektra, with Leonie Rysanek, clearly evokes a spirit of same sex attraction. 
When Strauss's prelude to the opera describes with characteristic realism the pleasures of the sex act and the curtain rises on the Marschallin and her young lover still in bed, the discovery that both are women was likely to produce in the audience a peculiar sensation of which the authors were certainly aware. ${ }^{26}$

Had Strauss portrayed homosexual androgyny only once, he would have been revered as a profound thinker. As Voltaire explained the virtues of homosexual intercourse to Frederick the Great: "Once, a philosopher; twice, a sodomite!"27 Strauss's penchant for gender mutability as titillation rendered him a pervert.

The importance of the epicene quality of Strauss operas to the sensibility of "camp" is paramount. As Susan Sontag suggests, it is one of the defining characteristics of the sensibility, and she singles out Der Rosenkavalier as a primary example: "When does travesty, impersonation, theatricality acquire the special flavor of Camp? Why is the atmosphere of Shakespeare's comedies (As You Like It, etc.) not epicene while that of Der Rosenkavalier is?"28 The sexual intermediary became a pervasive, if latent, force within early twentieth-century opera, as did its aesthetic parallel, "camp."

The scientific construction of sexuality and gender, with its medical and legal strictures, also manifested itself during the latter decades of the nineteenth century. By the early twentieth century, questions of sexuality and gender became a central focus of empirical pursuits. Cross-dressing is an integral component of Strauss's operas after 1910. Trouser roles in Der Rosenkavalier, Ariadne auf Naxos, and Arabella attest to the importance of the androgynous figure in his works. In Transvestites (1910), Magnus Hirschfield studied the phenomenon of cross-dressing from numerous angles: medical, psychological, legal and cultural. In his chapter entitled "Transvestism and the Stage," he employs the observations of Goethe to define the nature of theatrical cross dressing: "They do not present the thing, but rather the result of the thing." ${ }^{29}$ This "result" led to the identification of gender ambiguity with marginalized sexuality, which became known as "sexual intermediaries" or "inverts"-gays and lesbians. Gays and lesbians were thought of as a third gender. The phallocentric and openly misogynistic thinking of such figures as Otto Weininger often

26 Barbara Tuchman, "Neroism Is in the Air," in The Proud Tower: A Portrait of the World Before the War, 1890-1914 (New York: Bantam Books, 1967), 392.

27 Voltaire, cited in Leigh W. Rutledge, Unnatural Quotations (Boston: Alyson Press, 1988), 156.

28 Sontag, "Notes on Camp," 280.

29 Johann Wolfgang Goethe, cited in Magnus Hirschfield, Transvestites, trans. Michael A. Lombardi-Nash (Buffalo: Prometheus Books, 1991), 351. 
declared that male "inverts" contained the best of both worlds. Women who cross-dressed were often dismissed as inconsequential anomalies, or femmes fatales, attempting to gain power by imitating their superiors.

In opera, the feminine-masculine character was ubiquitous. Hirschfield provides a list of pants roles in opera beginning with Mozart and continuing through some fourty cross-dressed characters, all created before Strauss's contributions. $^{30}$

Der Rosenkavalier, set in the "romantic" past, the Vienna of the Habsburg monarchy, was Strauss's initial attempt to re-establish himself as a nonrevolutionary. Its reception however, was not in keeping with the new image he hoped to cultivate. Caricatures by several illustrators clearly suggest that the composer was still part of the world of psychosis and effete dandyism - the world of the pervert (figures 2,3, and 4). One need only compare these illustrations to Alfred Roller's original costume design to witness the labelling of the composer as sexual intermediary (figure 5).

Initial reviews of the work by Viennese critics were scathing. The Wiener Abendpost referred to the work as "wholly devoid of all humour; all that they offer in their work is cheap, low-class wit." The Weiner Allgemeine Zeitung called it "a farce, which sometimes sinks to the level of operetta, sometimes deeper still, to a burlesque set to music." 31 There was, however, no imperative need on the part of the composer to create a musical burlesque since he had already done so, quite unabashedly, in his Burleske for piano and orchestra of 1885. The composer was now in the situation of being a desperate intermediary, hopelessly tainted with the avant-garde label by some and with the reactionary label by others.

Der Rosenkavalier clearly has autobiographical implications. The Marschallin, like the composer who created her, also avoids the struggle of being a hero. Her first act monologue addresses the futility of heroism: "But why trouble myself? The world will have its way." This apostrophe to the ravages of time, the reluctance to wage a fight against the inevitable, to be a hero, all of this is as alien to the Marschallin as it was to Strauss. Her monologue, punctuated with sighs, both musically and textually, admits to the nihilism of operatic existence. Another touching reference and autobiographical admittance is made by Strauss through the Marschallin just before the final curtain of the opening act. She relates to Octavian her attempts to block the passage of time: "Sometimes I arise in the dead of night. And take the clocks and stop them every one - And yet-to

30 Hirschfield, Transvestites, 357.

31 Cited in Allan Jefferson, Richard Strauss: 'Der Rosenkavalier' (Cambridge: Cambridge University Press, 1985), 98-99. 


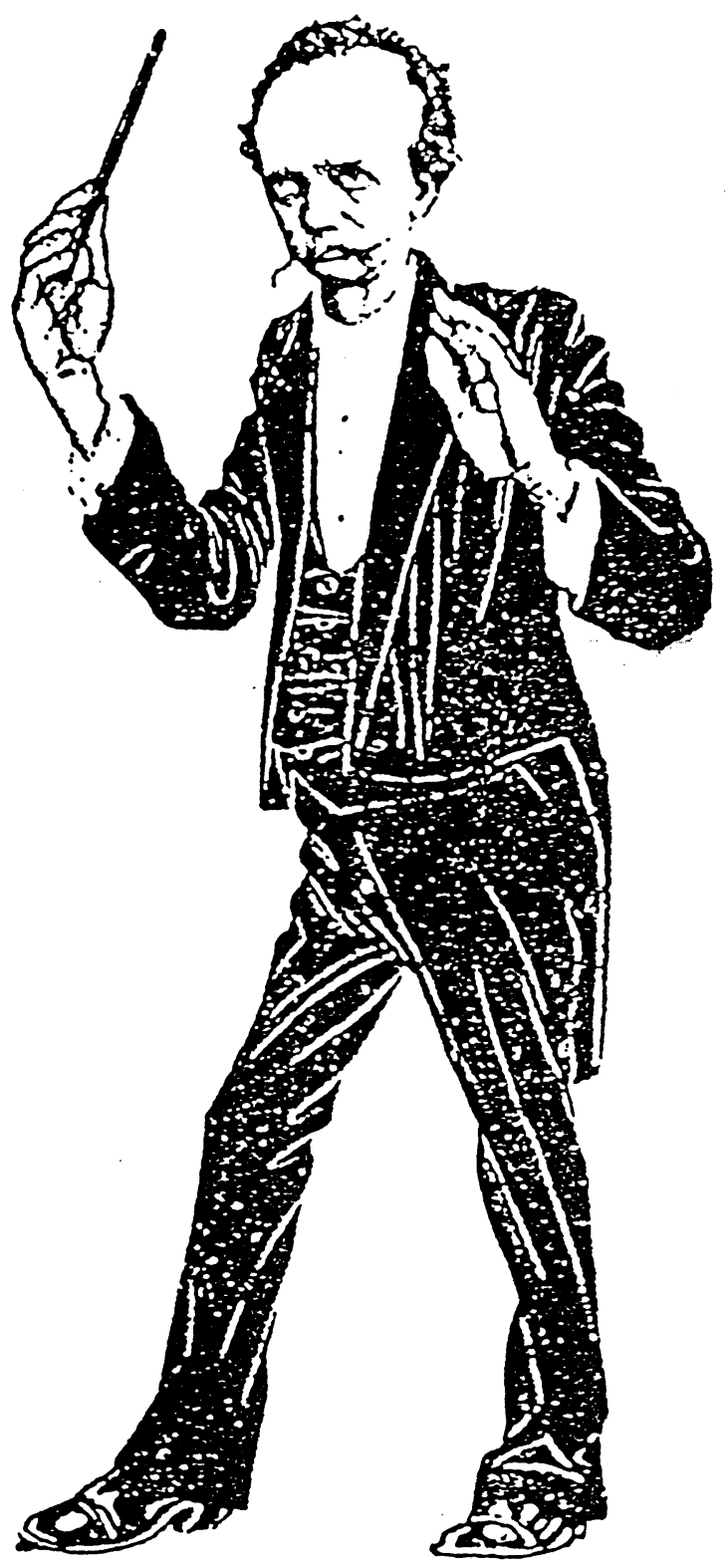

Figure 2: "Der Neurosenkavalier" (source unknown). 


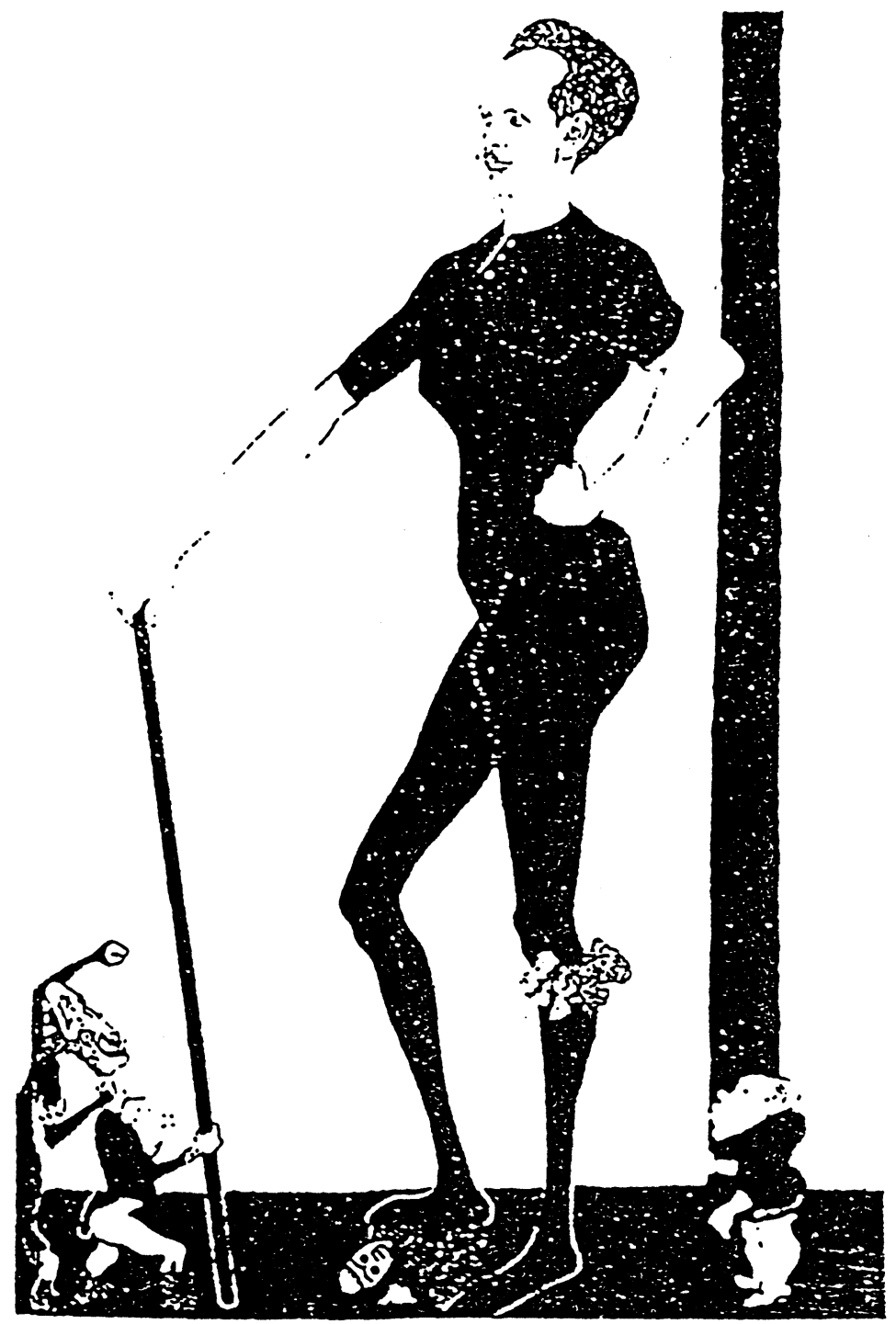

Figure 3: Richard Strauss. 


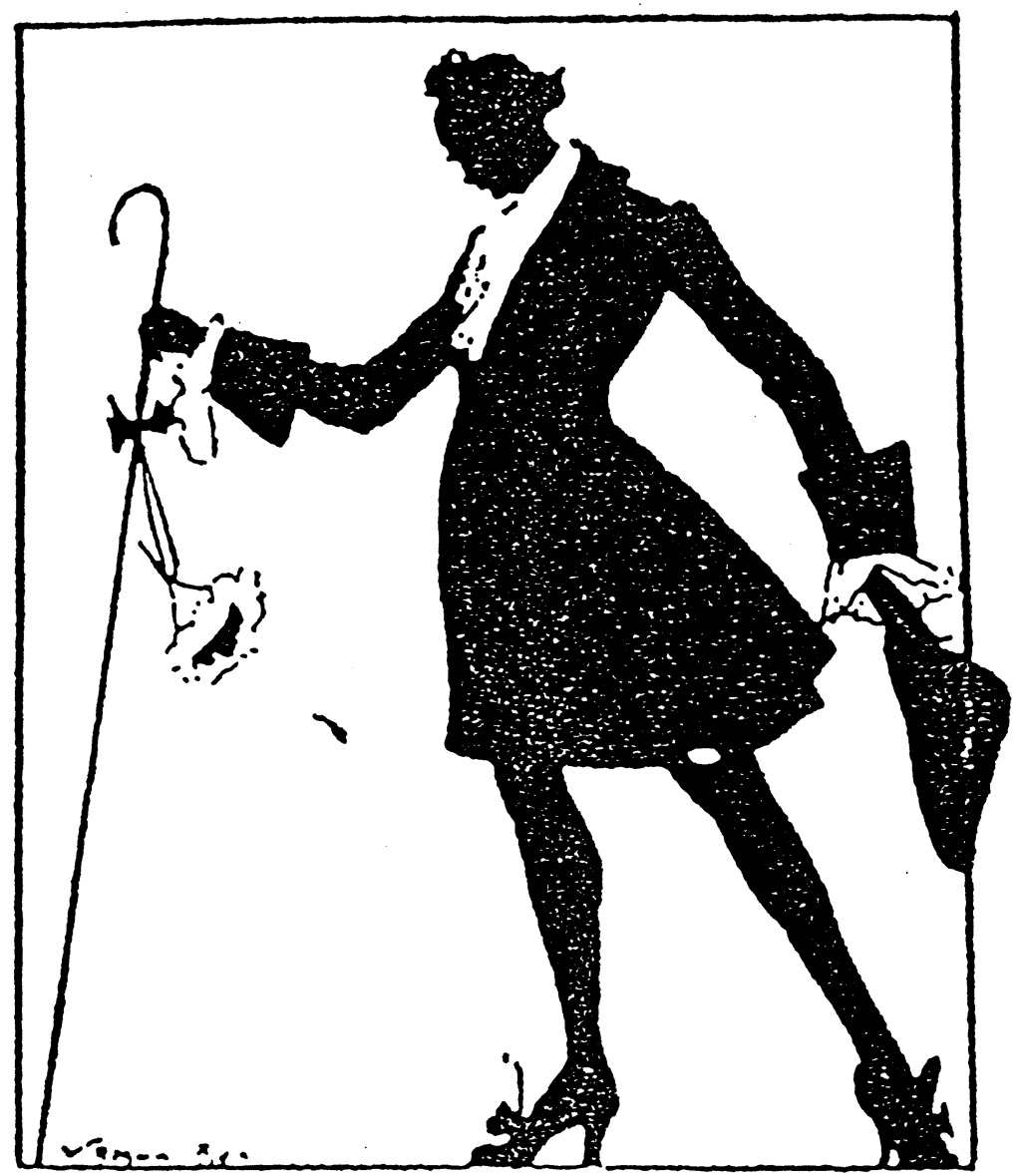

Figure 4: Richard Strauss.

be afraid of it - what profit is it?" Like Strauss, she surmises her own inevitable fate of becoming tediously dated and of being powerless against it.

The composer, and this work in particular, have often been criticized as being saccharin Viennese confections; these are also the attributes of his Marschallin. Catherine Clement, in Opera, or The Undoing of Women, describes her using just such language:

The marschallin: a little tender, a little soft, a brioche dipped too frequently in a cup of cocoa. Like Sanseverina, like Madame de Renal, like every aunt in love, the marschallin does not fight or scream. She cries in secret and walks straight ahead. From the moment Octavian climbs out of her bed she 


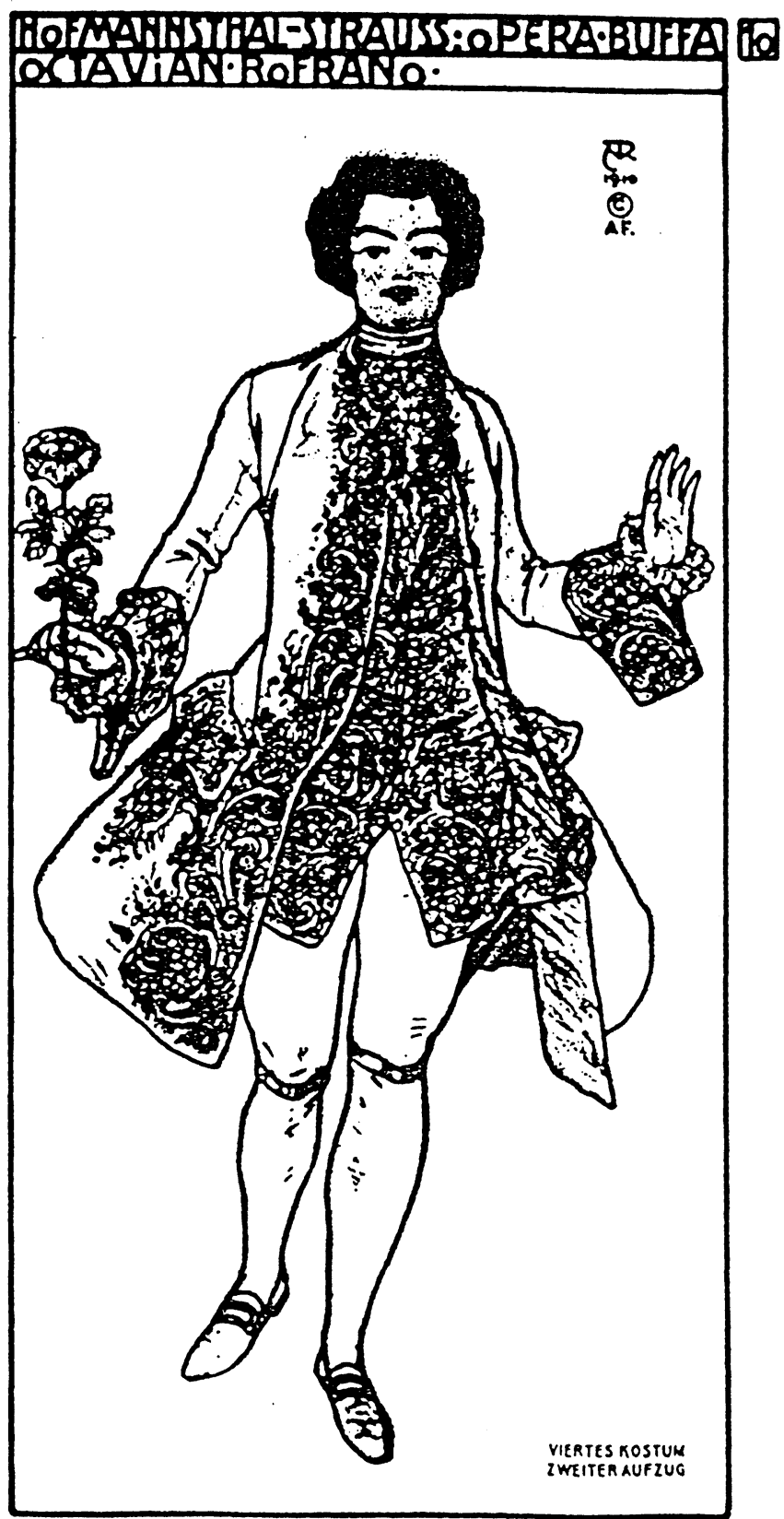

Figure 5 
spells out her own end. She daydreams while she dresses, imagines herself as she will be later, when she is old. She has no idea how soon that will be, she has no idea that at the moment when she is dressing, she ordains it will happen. She brushes her hair calmly and submerged in daydreams, puts on her makeup. ${ }^{32}$

The exploitation of extravagance and parody is clearly evoked from the onset of the opera. At measure 7 of the opera's Introduction he states that it is to be played "agitated and very extravagant in execution." A few measures later, he adds "the entire intensification from here on is to be thoroughly parodistic." 33 The features of artifice, extravagance and parody are all hallmarks of "camp" as defined by Sontag, who suggests that: "Camp introduces a new standard: artifice as an ideal, theatricality." 34

The artifice, parody and travesty in Der Rosenkavalier is to most observers a sign of the composer's "jaded view of youthful ardour." 35 However, the composer and librettist make no effort to hide their interest in portraying androgyny and transvestism in this opera. Hofmannsthal's initial conception of the work clearly indicates this intent. In a letter to Strauss from February of 1909, he states:

I have spent three quiet afternoons here drafting the full and entirely original scenario for an opera, full of burlesque situations and characters, with lively action, pellucid almost like a pantomime... . It contains two big parts, one for the baritone and another for a graceful girl dressed up as a man a la Farrar or Mary Garden. ${ }^{36}$

It is obvious in his correspondence that the work's earliest conception was centered on the two characters who are most closely linked with concepts of gender and sexuality. Baron Ochs (on whom the original title for the work was based) and Octavian allow the librettist and composer to expose the duality of not

32 Catherine Clement, Opera, or The Undoing of Women, trans. Betsy Wing (Minneapolis: University of Minnesota Press, 1988), 108.

33 The German instructions are Agitato und sehr überschwenglich im Vortrag, followed by die ganze Steigerung von hier ab durchaus parodistich. Richard Strauss, Der Rosenkavalier in Full Score (New York: Dover Publications, 1987), 1-2.

34 Sontag, "Notes on Camp," 288.

35 Charles Osborne, The Complete Operas of Richard Strauss (New York: Da Capo Press, 1988), 80.

36 The Correspondence Between Richard Strauss and Hugo von Hofmannsthal, trans. Hans Hammelman and Ewald Osers (Cambridge: Cambridge University Press, 1961), 27. 
just gender, but sexuality as well. The lecherous, debased lust of the Baron is contrasted with the ennobled and refined sentiments of Octavian. Few commentators have failed to notice and then exorcise the ghosts of homosexuality and lesbianism from the opera. The composer and librettist have both been blamed for the uncomfortable titillation of "invert" sexuality. Charles Osborne blames the composer for the "irrelevant piquancy:"

\begin{abstract}
Anyone unacquainted with the opera might easily mistake the situation at the rise of the curtain, and think he was witnessing a lesbian relationship. This adds a certain irrelevant piquancy to the flavour of the scene, but it is difficult not to feel that Strauss ought perhaps to have risen above his lack of interest in the tenor voice, and written the role of Octavian for a youthful lyric tenor. ${ }^{37}$
\end{abstract}

This epicene quality is certainly not an "irrelevant piquancy," rather it is a fundamental quality of the work itself.

William Mann also objects to the creation of the trouser-role. However, he places the blame squarely on the shoulders of the librettist. He suggests, in a clearly homophobic and sexist manner, that the composer remedied the "disastrous miscalculation" of the librettist by writing phallocentric music for Octavian:

It seems distasteful that Hofmannsthal should have cast so sexually virile a figure as a female role, particularly in the opening scene which demands overt demonstrations of the most passionate love-it is seldom that the two actresses involved manage to avoid suggesting a repellent sort of Lesbianism as they hug and caress one another, crooning torrid endearments. As if to atone for this disastrous miscalculation, Strauss leaves no doubt in the introduction to the first act that Octavian is a proper man. ${ }^{38}$

Of some signifigance here is he fact that Mary Garden, for whom the role of Octavian was envisioned, refused to create the role during her career, because of the overt lesbianism:

37 Osborne, 80.

38 William Mann, Richard Strauss: A Critical Study of the Operas (New York: Oxford University Press, 1966), 104. It is interesting that neither Osborne nor Mann seem concerned with the lecherous advances of Ochs upon Mariandel, with their covert gay overtones. Had the Baron been successful in his advances, it would have added a whole new dimension to the opera. One cannot help but wish that Strauss and Hofmannsthal would have taken that extra step. 
Oh, I didn't care for that opera at all. So I was just as glad that I hadn't created it at the Opera-Comique. Everybody said I would have made a wonderful Octavian. Perhaps. The role didn't appeal to me at all. Making love to women all night long would have bored me to death. ${ }^{39}$

William Mann is simply wrong in his assessment of the orchestral writing surrounding Octavian. Strauss is assuredly not apologizing for the ambivalence and titillation of the opening scene by employing "ejaculatory" horn calls. As a literal and figurative "intermediary," Octavian is made a member of both genders by the music. If the horn calls of the introduction are indeed the composer's negation of Hofmannsthal's travesty role, Strauss makes no attempt to maintain this in the opera. Paul Robinson, in Opera and Ideas, points out that in the second act the music which surrounds Octavian is androgynous, or perhaps feminine: "Octavian's affair with the Marschallin counts for nothing in this moment, and Strauss makes no effort to distinguish him, either musically or dramatically, from Sophie."40

Peter Stenberg argues that the composer's use of musical narrative creates a sense of heightened parody and irony:

Der Rosenkavalier for instance, has a rich variety of leitmotifs commenting constantly on the verbal action. This can be comical, as when the Marschallin complains of a headache to the accompaniment of the motif of love, or deeply serious, as when the first notes of the final trio repeats the music we hear as Ochs makes his grotesque attempt to ply Mariandel with wine. There is a deep connection between the comic and the serious, says the music, between tragedy of losing a lover to a younger woman and the comedy of seeing an older man try to seduce a young girl, who is actually a youth in disguise. ${ }^{41}$

Strauss's musical commentary is laced with "camp" irony. He musically equates the serious with the frivolous and vice-versa. However, it is not, as some critics have claimed, a burlesque set to music. Something much more profound and compelling is happening here-"camp," which, as Christopher Isherwood

39 Mary Garden and Louis Biancolli, Mary Garden's Story (New York: Simon \& Schuster, 1951), 220.

40 Paul Robinson, Opera and Ideas (New York: Harper and Row Publishers, 1985), 253.

41 Peter Stenberg, "Silence, Ceremony and Song in Hofmannsthal's Libretti," Seminar 16, no. 4 (November 1975): 213-14. 
points out, is the liberation of one's sensibility from the confines of having to be ardently sincere: "You see, true High Camp always has an underlying seriousness. You can't camp about something you don't take seriously. You're not making fun of it; your making fun out of it. You're expressing what's basically serious to you in terms of fun, artifice and elegance." ${ }^{2}$

Octavian functions as a fulcrum throughout the opera. Dramatically he stands as the "theatricalization of experience" the "result of the thing" as Goethe understands it. He is a male character portrayed by a female. This gender mutability is exploited throughout the opera. He/she is the fully initiated male lover of the Marschallin, the female love interest of the Baron and the adolescent naive "boyfriend" of Sophie. He/she is all things to all people as Benjamin Bennett points out: "Oktavian is both a real intermediary, as rose-bearer, and a symbolic mean, as hermaphrodite, between Ochs and Sophie, so that the main characters form a triangle, Marschallin-Ochs-Sophie, between each pair of which Oktavian holds the center." ${ }^{\text {"3 }}$ The ménage à trois imagery here is not subtle, nor should it be. This epicene campiness-the titillation of people negating their gender and sex roles-is an essential component of Strauss's creations. This requires adherence to a celebratory sensibility rather than one of sublimated innuendo.

At the opening of the Third Act of Der Rosenkavalier, Baron Ochs surveys his chambre separée. Here he hopes to seduce Mariandel, the transvestite version of Octavian. Waltz music can be heard from the offstage dance band prompting the Baron to query: "What's the music for? I didn't order it." Asked if he wants it brought closer, since it is "table music," he accepts it as part of the elaborate preparations to have his way with Mariandel, as long as it does not intrude upon his scheme: "Leave the music where it is!" is his response. The Baron is also haunted by the androgyny of his latest conquest. When he attempts to kiss Mariandel the image of Octavian reappears to him: "That face! Accursed boy! Pursues me whether I wake or dream!" Like the waltz tune which follows him wherever he goes the mutability of gender also haunts him. His admission of seeing Octavian-in his dreams-as he clumsily fails to connect with Mariandel is telling.

The homage to both Mozart and Johann Strauss throughout Der Rosenkavalier is common knowledge. However, in light of fin-de-siècle Viennese sensibility it takes on a more pronounced cultural meaning. The waltz rhythm which perme-

42 Christopher Isherwood, The World in the Evening (New York: Farrar, Straus \& Giroux, 1952), 110.

43 Benjamin Bennett, Hugo von Hofmannsthal: The Theatres of Consciousness (Cambridge: Cambridge University Press, 1988), 241. 
ates the opera stands is not just a Viennese musical accent or dialect. Rather, it is the acknowledgment of sexuality and the world of the transvestite and by connection the homosexual as modernist figure. This is already presupposed in the waltz section from the Dance of the Seven Veils in Salome. The composer sets about to portray the sensuality and sexuality of a truly exotic situation. However, within moments the "oriental" accent gives way to the sensual quality of the waltz. The borrowing of the aristocratic cross-dressed figure from Die Fledermaus by Johann Strauss carried with it a tacit acknowledgment of "invert" sexuality. Charles Michael Carroll points to Orlofsky as not just a patron of the arts but other things as well:

It is also in Die Fledermaus that we find one of the most daring moves in nineteenth-century opera, the introduction of a homosexual on the stage. There seems to be no record of anyone objecting to this idea, although it is obvious that when Prince Orlofsky sings his famous line, "Chacun à son goût," he means not what people do for amusement at his party, but how they seek pleasure in other matters as well. ${ }^{44}$

Perceiving the impossibility of escape from the burden of "serious" art, Strauss and Hofmannsthal retreated into the genre of opera itself. With its history of absurdity, artifice and theatricality it was the only vehicle available in which to detour around the burden of "serious" art. As Adorno suggests: "The closer opera gets to a parody of itself, the closer it is to the principle most inherent to it." 45 By the final act, the plot and its musical manifestations have taken so many twists that an operatic convention of the highest magnitude was called for. Their response was to rely upon one of the oldest and most ennobling gestures in the operatic canon, one which Adorno clearly identifies with artifice and exaggeration. This is claimed by Adorno as being a "refreshment:"

The most extreme example of this is probably the passage from Der Rosenkavalier, over the organ point B flat upon the entrance of the Marschallin in the third act as deus ex machina; already, it may be noted, the passage lacks dissonance. In this act the action finds its nocturnal kairos, identified with the heartbreaking passion of the lovers who have lost

44 Charles Michael Carroll, "Eros on the Operatic Stage: Problems of Manners and Morals," Opera Quarterly 1, no. 1 (Spring 1983): 42.

45 Adorno, "Bürgerliche Oper," in Gesammelte Schriften, vol. 16, ed. Rolf Tiedemann (Frankfurt: Suhrkamp, 1978), 24; quoted and translated in Herbert Lindenberger, Opera: The Extravagant Art (Ithaca: Cornell University Press, 1984), 80. 
themselves senselessly. Such moments musicaux are heralds in Strauss's modernism of a future yet to be realized; at the same time, they are by no means always "advanced" in terms of their materials. ${ }^{46}$

Octavian as "invert" intermediary, the Marschallin as a cocoa-soaked deus ex machina, Richard Strauss as neurotic pervert, and Hofmannsthal as the weaver of conscious dandyism; the "camp" characteristics are all evident. Committed to the seriousness of artifice and elegance, Der Rosenkavalier heralds not a capitulation to bourgeois escapism, but rather a celebration of the success of avoiding bourgeois heroism. As Sontag suggests: "Camp doesn't propose that it is in bad taste to be serious; it doesn't sneer at someone who succeeds in being seriously dramatic. What it does is to find the success in certain passionate failures." 47

What opera, and Der Rosenkavalier in particular, does is to show us that sensibilities, like ideas and behaviour, belong to the realm of art. Der Rosenkavalier is essentially a masquerade of a masquerade. "Camp" functions as a mirror upon which mirror images of our anxieties are reflected. Like Oscar Wilde's claim that "One should either be a work of art, or wear a work of art," ${ }^{48}$ Der Rosenkavalier does just that. It $i$ a work of art while simultaneously clothing itself in the artistic fabric of the operatic genre. Benjamin Bennett evaluates its importance this way: "By building its sentimentality [sensibility?] on an intellectual basis, on our understanding that the process we are involved in is artificial, that it belongs to culture not nature, Der Rosenkavalier perhaps teaches that our emotional life is not prior to our cultural existence but derived from it." 49

Strauss has fully identified himself with the rejection of the propriety of belonging to "serious" art. He has adopted the posture and understanding that "the sensibility of high culture has no monopoly upon refinement." 50 Der Rosenkavalier nurtures itself on the adoration of the emotional, the mundane, and the non-heroic. It is the triumph of style over content, taste over stale intellectualism and of sensibility over nihilism. Richard Strauss was consciously, perhaps painfully, aware of the fate of "revolutionaries" in turn of the century Europe-they were a tortured lot. His survival depended upon his being

46 Adorno, "Richard Strauss, Part II," trans. Samuel and Shierry Weber, in Perspectives of New Music 4 (Spring/Summer 1966): 118.

47 Sontag, "Notes on Camp," 291.

48 Oscar Wilde, Phrases and Philosophies for the Use of the Young, cited in Epigrams \& Aphorisms by Oscar Wilde (Boston: John W. Luce, 1905), 67.

49 Bennett, 242.

50 Sontag, "Notes on Camp," 291. 
naive enough to believe that no one would notice his "perverse" modernist tendencies, and if they did, they wouldn't give a damn.

\section{Abstract}

In her celebrated essay, "Notes on Camp," Susan Sontag identifies Richard Strauss's most famous opera, Der Rosenkavalier as forming part of the canon of "camp." What is it about this work and its relationship to fin-de-siècle Vienna which gives it over to the "camp" aesthetic?

In this article, the author examines the essence of the style known as camp, as derived from kitsch, another mode of "failed seriousness." Central to this investigation is the maner in which certain aesthetic objects can inhabit the realms of "high" or "serious" art and also that of popular culture. Hermann Broch, Theodor Adorno, and others suggest that kitsch is a parasitic ingredient in bourgeois culture and that this element can invade and "negate" an aesthetic object or experience. The historical imperatives found in romantic opera, bourgeois culture, and marginalized groups form an important element in defining the creations of modernist culture.

Part of our understanding of what constitutes "serious" art has at its centre ways of maintaining autonomy and refusing the prospect of "negating" itself. One way of experiencing and examining those works which "refuse the burden of autonomy" is through the categories of questionable or marginal sensibilities, in this case: kitsch and camp.

Der Rosenkavalier, with its fawning tribute to eighteenth-century Vienna, overt homage to Mozart, and its heralding of the composer's withdrawal from the avant-garde, proves to be a superb example of alternative sensibilities. 